\title{
Effect of Wastewaters on Concentration of Micronutrients in Dominant Soils of North Karnataka, India
}

\author{
Hanamantarao Jogan* and G.S. Dasog \\ Department of Soil Science and Agricultural Chemistry, UAS, Dharwad - 580 005, India \\ *Corresponding author
}

\section{Keywords}

Wastewater, Water quality, Lateritic, Red and black soil

Article Info

\section{Accepted:}

10 March 2019

Available Online:

10 April 2019

\section{A B S T R A C T}

Water scarcity and increase wastewater generation are twin problem associated which needs to be addressed to derive benefit for agricultural production. In this context laboratory study was conducted to characterize the wastewater from four different sources (Ugar sugar-Ugar khurd, West coast paper mill-Dandeli, Nectar beverages-Dharwad, Domestic sewage water-UAS campus Dharwad) in north Karnataka and were compared with freshwater. Spentwash from the Ugar Sugar Works distillery was singularly different from rest of the wastewaters and was characterized by its high $\mathrm{pH}$, EC, TSS, TDS, BOD, COD, total nitrogen, phosphate, potassium and sulphate concentration. The effect of the wastewaters on the dominant soils of north Karnataka (Red, Lateritic and Black soil) were evaluated in column study during March-2014 to April-2015. Wide variation in water characteristics was recorded with wastewaters studied. Application of 8 pore volumes of different wastewaters increased $\mathrm{Fe}, \mathrm{Cu}, \mathrm{Mn}, \mathrm{Zn}$ and $\mathrm{B}$ of the soils over freshwater application. Among the wastewaters, biomethanated spentwash induced greater influence on the recorded soil parameters. Higher values of the observed soil parameter were recorded in the surface soil $(0-15 \mathrm{~cm})$ in comparison to other depths $(15-30 \mathrm{~cm}, 30-45 \mathrm{~cm}$ and $45-60 \mathrm{~cm})$.

\section{Introduction}

Increasing scarcity of water has turned to be regular phenomenon in the recent past. Priorities of the water use have also being changing with increased demand from the other sectors creating competition for the water use in agriculture sector. Rapid population increase in urban areas and industrialization gives rise to concern about appropriate water management practices. Surface waters are being polluted by means of wastes or effluent discharge from the industries, domestic sewage, and municipal wastes etc. Further land application of wastewater is now becoming one of the most economically and ecologically viable method of disposal of these waters. With rapid expansion of cities and domestic water supply, quantity of grey/wastewater is increasing in the same proportion. Overall analysis of water resources indicates that in coming years, there will be a twin edged problem to deal with reduced fresh water 
availability and increased wastewater generation. Non-conventional water resources play greater role for water augmentation to achieve food security in water-scarce countries in the near future. Urban agriculture using wastewater provides food, income and employment to thousands of people. Nevertheless, reusing wastewater in agriculture is considered a deleterious practice since it may introduce pollutants to the environment, spread waterborne diseases, chemical contamination, soil salinization and contamination of groundwater sources, generate odour problems and result in aversion to the crops (IWMI, 2006). Contrarily, this kind of reuse may result in some benefits for soils, crops and farmers. Nowadays, the reuse of wastewater in agriculture is seen in some countries as a convenient environmental strategy. Globally around 3 to 3.5 million hectares are irrigated with raw and diluted wastewater irrigation. Wastewater is therefore, considered an appropriate option for reuse. Wastewater contains a significant load of biodegradable organic material and nutrients which are necessary for the growth of crops. Accumulation of organic matter in soil by irrigation with wastewater can be beneficial as it may result in the enhancement of physical structure of the soil, the increase in soil microbial activity and improvement of soil performance as a filter and degrading media for pollutants.

The consistent use of wastewater in irrigation may stabilize the content of nutrients in the soil, even when growing crops with high nutritional requirements; this is because the continuous withdrawal of nutrients by plants is compensated by the constant input of organic and mineral components into the soil via wastewater. Effect of sewage wastewater on black soil (Varkey et al., 2015), paper mill wastewater on red soil (Sharma et al., 2014) and spentwash on black soil (Singh and
Swami, 2014) have been studied. Composite study on characterization of the wastewater and their effect of different wastewaters on a wide range of soil is sparse. Information on effect of wastewater on a wide range of dominant soils of north Karnataka under controlled laboratory condition would give an insight into their capacity to bear the load of different chemical constituents. Thus a comprehensive study on the effect of different wastewaters characterized by different properties on different soil types was planned and executed under laboratory conditions.

\section{Materials and Methods}

The investigation was carried out by using three dominant soils of north Karnataka viz., Red (Ustropepts), Lateritic (Kanhaplic Haplustalfs), and Black soils (Typic Haplusterts). Four different water sources employed were domestic sewage, paper mill wastewater, soft drink factory wastewater, distillery spentwash and compared with fresh water (borewell water).

The wastewater samples were collected from different sources was used for the column study. For the column study $5 \mathrm{~cm}$ diameter PVC pipes of $60 \mathrm{~cm}$ long with perforated bottom end caps were used. Initially the BD of each soil sample was measured, based on the BD and pipe column parameters (length and diameter) the quantity of soil filled in the each soil column was calculated.

Volume of pipe column $=\pi \mathrm{r}^{2} \mathrm{~h}, \mathrm{r}=2.5 \mathrm{~cm}$, $\mathrm{h}=60 \mathrm{~cm}$,

Volume of pipe column $=1178.25 \mathrm{~cm}^{3}$,

Weight of soil in column $=$ Volume $\times$ BD

Each soil samples were properly processed and passed through $2 \mathrm{~mm}$ sieve, before filling the columns. Amount water added in each column was based on maximum water holding capacity of different soils. Irrigation 
was given in terms of pore volumes, totally 8 pore volumes were passed through soil columns at an interval of 10 days. After passing two pore volumes one set of column was horizontally sectioned at an interval of 15 $\mathrm{cm}$.

\begin{tabular}{|l|l|l|l|l|}
\hline Soils & BD $\left(\mathbf{g ~ c m}^{-3}\right)$ & $\begin{array}{l}\text { Quantity of } \\
\text { soil added }\end{array}$ & MWHC (\%) & $\begin{array}{l}\text { Amount of water added } \\
\text { per one pore volume } \\
\text { (kg) }\end{array}$ \\
\hline Red & 1.45 & 1.71 & 48.5 & 828 \\
\hline Lateritic & 1.52 & 1.80 & 50.5 & 903 \\
\hline Black & 1.34 & 1.57 & 67 & 1057 \\
\hline
\end{tabular}

Experiment was conducted using two factorial CRD with three replication. Factor I included different wastewater sources (1. Domestic sewage water- UAS Dharwad, 2. Soft drink factory treated wastewater- Nectar beverages, Dharwad, 3. Paper mill treated wastewaterWest Coast Paper mill Dandeli, 4. Distillery biomethanated spentwash (diluted with normal water in the ratio of 1:3) - Ugar sugar works Ugar khurd and 5. Normal water- Fresh borewell water UAS Dharwad) and factor II comprised of different soil depths $(0-15 \mathrm{~cm}$, $15-30 \mathrm{~cm}, 30-45 \mathrm{~cm}$ and $45-60 \mathrm{~cm}$ ).

The $\mathrm{pH}$ and $\mathrm{EC}$ of the waters were analyzed immediately after bringing the samples using $\mathrm{pH}$ meter and Systronics direct digital conductivity meter-304, respectively as described by Tandon (1998). The dissolved solids in the effluents were determined by gravimetric method. The suspended solids in the effluents were determined by filtration method (Tandon, 1998).

The Biological oxygen demand (BOD) of effluents were determined by measuring the dissolved oxygen of the samples before and after incubation at $20^{\circ} \mathrm{C}$ for five days by titrating it against sodium thiosulphate using starch indicator and the BOD of sewage water was calculated as described by Tandon (1998). The Chemical oxygen demand (COD) of wastewater was determined by open reflux method. The total nitrogen in water samples was determined titrimetrically after distilling the $\mathrm{NH}_{3}$ in boric acid mixed indicator. The phosphates in the effluents were determined by chloro-stannous reduced blue colour method. Potassium in the effluents was determined by using the flame photometer with suitable dilutions as described by Tandon (1998).

The $\mathrm{pH}$ of soil was determined in 1: 2.5 soils to water suspension after stirring the samples intermittently for half an hour using a Systronics direct digital $331 \mathrm{pH}$ meter. Electrical conductivity of the soil was determined in the supernatant of 1:2.5 soils to water suspension by using Systronics direct digital conductivity meter-304 (Sparks et al., 1996). The organic carbon content was determined by taking finely ground sample by wet oxidation method as described by Jackson (1967). The available boron in soil was extracted by hot water (Hesse, 2002) and the extracted boron was then treated with curcumin-oxalic acid reagent and the intensity of color developed was measured by spectrophotometer at $540 \mathrm{~nm}$. Micronutrients in the soil samples were extracted by using DTPA extractant and the content of $\mathrm{Fe}, \mathrm{Zn}$, $\mathrm{Cu}$ and $\mathrm{Mn}$ were measured by atomic absorption spectrophotometer (Lindsay and Norvell, 1978). The experimental data was statistically analyzed as per Gomez and Gomez (1984) for soil chemical properties.

The computed data was interpreted with a critical differences level at 1 per cent. 


\section{Results and Discussion}

The $\mathrm{pH}$ of sewage water and the wastewater from paper mill were near neutral whereas those from soft drink factory and distillery biomethanated spentwash were alkaline. The EC of paper mill and soft drink factory wastewaters were around $2 \mathrm{dS} \mathrm{m}^{-1}$ whereas the sewage water was $1.23 \mathrm{dS} \mathrm{m}^{-1}$ closely followed by the normal water of the campus. The spentwash from the Ugar Sugar Works distillery was the most saline with an EC of
$11.54 \mathrm{dS} \mathrm{m}^{-1}$ and in many other properties such as TDS, TSS, BOD, COD, Total N, P and $\mathrm{K}$ contents was singularly different from rest of the wastewaters (Table 1).

With respect to total $\mathrm{N}, \mathrm{P}$ and $\mathrm{K}$, the remaining three wastewaters had similar content. The sewage water was characterized by its high TSS, TDS, BOD and COD, the values of which were much less in soft drink factory wastewater and paper mill wastewater except for high TDS and COD (Table 2).

Table.1 Initial properties of soils studied

\begin{tabular}{|c|c|c|c|}
\hline Properties & Red soil & Lateritic soil & Black soil \\
\hline pH (1:2.5) & 6.15 & 5.60 & 7.10 \\
\hline$E C\left(d S ~ m^{-1}\right)$ & 0.14 & 0.28 & 0.21 \\
\hline $\mathrm{OC}\left(\mathrm{g} \mathrm{kg}^{-1}\right)$ & 8.0 & 4.6 & 4.7 \\
\hline Available Boron (mg kg $\left.{ }^{-1}\right)$ & 0.88 & 0.47 & 0.48 \\
\hline Available Copper $\left(\mathrm{mg} \mathrm{kg}^{-1}\right)$ & 4.77 & 0.36 & 1.31 \\
\hline Available Zinc (mg kg-1) & 1.01 & 0.23 & 0.39 \\
\hline Available Iron $\left(\mathrm{mg} \mathrm{kg}^{-1}\right)$ & 33.2 & 10.3 & 10.5 \\
\hline Available Manganese $\left(\mathrm{mg} \mathrm{kg}^{-1}\right)$ & 59.6 & 19.0 & 23.4 \\
\hline
\end{tabular}

Table.2 Chemical composition of water samples

\begin{tabular}{|c|c|c|c|c|c|}
\hline Parameters & Sewage & $\begin{array}{l}\text { Soft drink } \\
\text { factory }\end{array}$ & Paper mill & Spentwash & $\begin{array}{c}\text { Normal } \\
\text { water }\end{array}$ \\
\hline pH & 7.33 & 8.14 & 7.4 & 8.3 & 6.91 \\
\hline $\mathrm{EC}(\mathrm{dS} / \mathrm{m})$ & 1.23 & 2.09 & 1.85 & 11.54 & 0.72 \\
\hline $\operatorname{TSS}\left(\mathrm{mg} \mathrm{L}^{-1}\right)$ & 480 & 18 & 36 & 1115 & 8 \\
\hline $\operatorname{TDS}\left(\mathrm{mg} \mathrm{L}^{-1}\right)$ & 662 & 30 & 748 & 1975 & 12 \\
\hline BOD $\left(\mathrm{mg} \mathrm{L}^{-1}\right)$ & 256 & 8.29 & 21 & 1800 & 9 \\
\hline $\operatorname{COD}\left(\mathrm{mg} \mathrm{L}^{-1}\right)$ & 410 & 27 & 158 & 4508 & 14 \\
\hline $\mathrm{Ca}+\operatorname{Mg}\left(\operatorname{meq~L}^{-1}\right)$ & 8.6 & 4.8 & 5.6 & 13 & 4.0 \\
\hline Sodium (meq $\left.\mathbf{L}^{-1}\right)$ & 6.30 & 6.86 & 7.08 & 8.69 & 3.26 \\
\hline Total-N (mg L L & 23.7 & 20.57 & 25.4 & 130.4 & 1.25 \\
\hline Total-P $\left(\mathbf{m g ~ L}^{-1}\right)$ & 13.45 & 8.25 & 10.34 & 28 & 0.10 \\
\hline Total $-\mathrm{K}\left(\mathrm{meq} \mathbf{L}^{-1}\right)$ & 0.74 & 0.72 & 1.35 & 39 & 0.20 \\
\hline $\mathrm{NO}_{3}=\mathrm{N}\left(\mathrm{mg} \mathrm{L}^{-1}\right)$ & 1.69 & 1.45 & 1.78 & 2.85 & 0.75 \\
\hline Sulphate $\left(\mathrm{mg} \mathrm{L}^{-1}\right)$ & 7.22 & 7.87 & 8.13 & 9.25 & 2.5 \\
\hline
\end{tabular}


Table.3 Available boron $\left(\mathrm{mg} \mathrm{kg}^{-1}\right)$ in red and lateritic soils after passing different pore volumes of various wastewaters

\begin{tabular}{|c|c|c|c|c|c|c|c|c|c|c|c|c|c|c|c|}
\hline \multicolumn{6}{|c|}{ Red soil } & \multirow{2}{*}{\multicolumn{5}{|c|}{$\begin{array}{l}\text { Lateritic soil } \\
8 \text { pore volumes }\end{array}$}} & \multirow{2}{*}{\multicolumn{5}{|c|}{$\begin{array}{c}\text { Black soil } \\
\mathbf{8} \text { pore volumes } \\
\end{array}$}} \\
\hline \multirow[t]{2}{*}{ W/S } & \multicolumn{5}{|c|}{8 pore volumes } & & & & & & & & & & \\
\hline & D1 & D2 & D3 & D4 & $\mathbf{M}$ & D1 & D2 & D3 & D4 & $\mathbf{M}$ & D1 & D2 & D3 & D4 & $\mathbf{M}$ \\
\hline W1 & 2.40 & 1.30 & 1.10 & 1.00 & 1.45 & 0.91 & 0.85 & 0.76 & 0.65 & 0.79 & 1.30 & 1.21 & 1.00 & 0.92 & 1.11 \\
\hline W2 & 1.80 & 1.30 & 1.20 & 1.00 & 1.33 & 0.82 & 0.66 & 0.59 & 0.53 & 0.65 & 1.22 & 1.08 & 0.92 & 0.84 & 1.02 \\
\hline W3 & 1.95 & 1.40 & 1.40 & 1.20 & 1.49 & 0.86 & 0.72 & 0.65 & 0.57 & 0.70 & 1.25 & 1.13 & 0.95 & 0.86 & 1.05 \\
\hline W4 & 2.90 & 1.50 & 1.40 & 1.30 & 1.78 & 1.53 & 1.21 & 0.94 & 0.83 & 1.13 & 1.63 & 1.33 & 1.25 & 1.19 & 1.35 \\
\hline W5 & 1.20 & 1.00 & 0.70 & 0.70 & 0.90 & 0.62 & 0.52 & 0.42 & 0.33 & 0.47 & 0.63 & 0.53 & 0.43 & 0.32 & 0.48 \\
\hline Mean & 2.05 & 1.30 & 1.16 & 1.04 & 1.39 & 0.95 & 0.79 & 0.67 & 0.58 & 0.75 & 1.21 & 1.06 & 0.91 & 0.83 & 1.00 \\
\hline \multirow[t]{2}{*}{$\mathbf{W}$} & \multicolumn{2}{|c|}{ S.Em \pm} & \multicolumn{3}{|c|}{ CD at $1 \%$} & \multicolumn{2}{|c|}{ S.Em \pm} & \multicolumn{3}{|c|}{ CD at $1 \%$} & \multicolumn{2}{|c|}{ S.Em \pm} & \multicolumn{3}{|c|}{ CD at $1 \%$} \\
\hline & \multicolumn{2}{|c|}{0.008} & \multicolumn{3}{|c|}{0.03} & \multicolumn{2}{|c|}{0.006} & \multicolumn{3}{|c|}{0.02} & \multicolumn{2}{|c|}{0.009} & \multicolumn{3}{|c|}{0.03} \\
\hline D & \multicolumn{2}{|c|}{0.008} & \multicolumn{3}{|c|}{0.03} & \multicolumn{2}{|c|}{0.005} & \multicolumn{3}{|c|}{0.02} & \multicolumn{2}{|c|}{0.008} & \multicolumn{3}{|c|}{0.03} \\
\hline WxD & \multicolumn{2}{|c|}{0.017} & \multicolumn{3}{|c|}{0.06} & \multicolumn{2}{|c|}{0.012} & \multicolumn{3}{|c|}{0.05} & \multicolumn{2}{|c|}{0.017} & \multicolumn{3}{|c|}{0.07} \\
\hline $\begin{array}{l}\mathrm{W} 1-\mathrm{S} \\
\mathrm{D} 1=0\end{array}$ & $\begin{array}{l}\text { ge wate } \\
5 \mathrm{~cm} \mathrm{de}\end{array}$ & & $\begin{array}{l}\text { W2- Sof } \\
\text { D2 }=15\end{array}$ & $\begin{array}{l}\text { Irink fac } \\
30 \mathrm{~cm} \mathrm{c}\end{array}$ & $\begin{array}{l}\text { y waste } \\
\text { th }\end{array}$ & & $\begin{array}{l}\text { paper } \\
=30 \text { to }\end{array}$ & $\begin{array}{l}\text { wastev } \\
\mathrm{cm} \text { dep }\end{array}$ & & $\begin{array}{l}\text {-distille } \\
=45 \text { to }\end{array}$ & 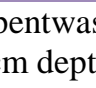 & & $\begin{array}{l}\text { W5- no } \\
\mathrm{M}-\mathrm{Me}\end{array}$ & $\begin{array}{l}\text { tap wat } \\
\text { each val }\end{array}$ & \\
\hline
\end{tabular}

mean of triplicates) 
Table. $4 \mathrm{Cu}\left(\mathrm{mg} \mathrm{kg}^{-1}\right)$ status in red, lateritic and black soils after passing 8 pore volumes of wastewaters

\begin{tabular}{|c|c|c|c|c|c|c|c|c|c|}
\hline \multicolumn{4}{|c|}{ Red soil } & \multirow{2}{*}{\multicolumn{3}{|c|}{$\begin{array}{l}\text { Lateritic soil } \\
8 \text { pore volumes }\end{array}$}} & \multirow{2}{*}{\multicolumn{3}{|c|}{$\begin{array}{c}\text { Black soil } \\
8 \text { pore volumes }\end{array}$}} \\
\hline \multirow[t]{2}{*}{ W/S } & \multicolumn{3}{|c|}{8 pore volumes } & & & & & & \\
\hline & D1 & D4 & $\mathbf{M}$ & D1 & D4 & $\mathbf{M}$ & D1 & D4 & $\mathbf{M}$ \\
\hline W1 & 5.98 & 5.04 & 5.51 & 0.77 & 0.52 & 0.65 & 2.50 & 2.35 & 2.43 \\
\hline W2 & 5.36 & 4.86 & 5.11 & 0.78 & 0.55 & 0.67 & 2.57 & 2.34 & 2.46 \\
\hline W3 & 5.27 & 4.73 & 5.00 & 0.80 & 0.57 & 0.69 & 2.60 & 2.36 & 2.48 \\
\hline W4 & 7.44 & 6.77 & 7.10 & 1.05 & 0.73 & 0.89 & 4.34 & 3.18 & 3.76 \\
\hline W5 & 4.92 & 4.62 & 4.77 & 0.37 & 0.34 & 0.36 & 1.38 & 1.23 & 1.31 \\
\hline Mean & 5.80 & 5.20 & 5.50 & 0.75 & 0.54 & 0.65 & 2.68 & 2.29 & 2.49 \\
\hline \multirow[t]{2}{*}{$\mathbf{W}$} & \multicolumn{2}{|l|}{ S.Em \pm} & CD at $1 \%$ & \multicolumn{2}{|l|}{ S.Em \pm} & CD at $1 \%$ & \multicolumn{2}{|c|}{ S.Em \pm} & CD at $1 \%$ \\
\hline & \multicolumn{2}{|l|}{0.014} & 0.06 & \multicolumn{2}{|l|}{0.003} & 0.01 & \multicolumn{2}{|c|}{0.010} & 0.04 \\
\hline D & \multicolumn{2}{|l|}{0.013} & 0.05 & \multicolumn{2}{|l|}{0.003} & 0.01 & \multicolumn{2}{|c|}{0.009} & 0.03 \\
\hline WxD & \multicolumn{2}{|l|}{0.029} & & \multicolumn{2}{|l|}{0.006} & & \multicolumn{2}{|c|}{0.020} & 0.08 \\
\hline $\begin{array}{l}\text { W1-Sew } \\
\text { D1 }=0 \text { to } \\
\text { mean of }\end{array}$ & & Soft dri & $\begin{array}{l}\text { y wast } \\
\text { th }\end{array}$ & $\begin{array}{l}\text { W3- } \\
\text { D3= }\end{array}$ & $\begin{array}{l}\text { mill we } \\
45 \mathrm{~cm}\end{array}$ & & $\begin{array}{l}\text { ery spe } \\
60 \mathrm{~cm}\end{array}$ & $\begin{array}{l}\text { W5- no } \\
\text { M-M }\end{array}$ & $\begin{array}{l}1 \text { tap water } \\
\text { (each values }\end{array}$ \\
\hline
\end{tabular}


Table.5 Zn (mg kg-1) status in red, lateritic and black soils after passing 8 pore volumes of wastewaters

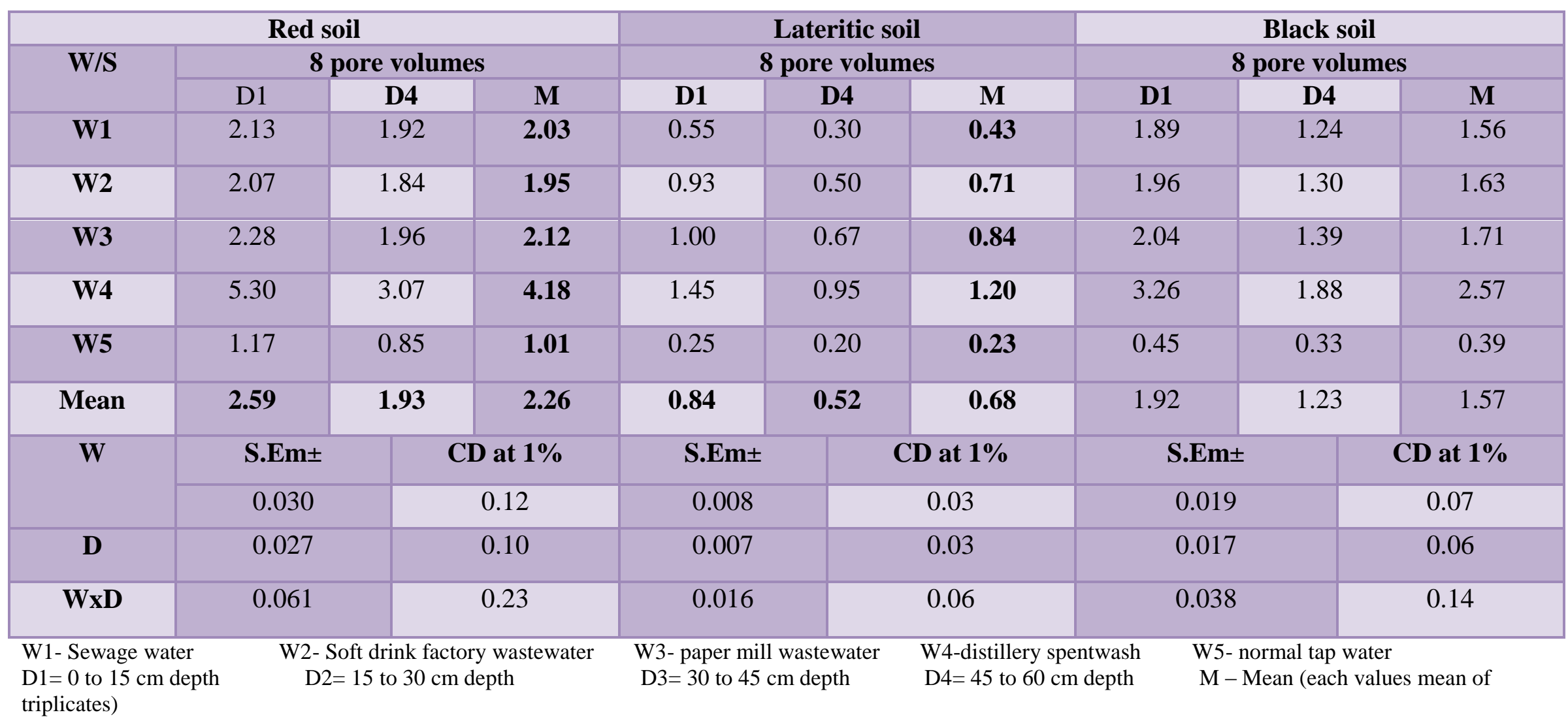


Table.6 Fe (mg kg-1) status in red, lateritic and black soils after passing 8 pore volumes of wastewaters

\begin{tabular}{|c|c|c|c|c|c|c|c|c|c|}
\hline \multicolumn{4}{|c|}{ Red soil } & \multirow{2}{*}{\multicolumn{3}{|c|}{$\begin{array}{c}\text { Lateritic soil } \\
\mathbf{8} \text { pore volumes }\end{array}$}} & \multirow{2}{*}{\multicolumn{3}{|c|}{$\begin{array}{c}\text { Black soil } \\
8 \text { pore volumes }\end{array}$}} \\
\hline \multirow[t]{2}{*}{ W/S } & \multicolumn{3}{|c|}{8 pore volumes } & & & & & & \\
\hline & D1 & D4 & $\mathbf{M}$ & D1 & D4 & $\mathbf{M}$ & D1 & D4 & $\mathbf{M}$ \\
\hline W1 & 51.2 & 38.4 & 44.8 & 13.4 & 11.9 & 12.7 & 16.9 & 14.1 & 15.5 \\
\hline W2 & 52.8 & 40.6 & 46.7 & 14.0 & 12.6 & 13.3 & 17.7 & 15.3 & 16.5 \\
\hline W3 & 51.4 & 38.8 & 45.1 & 13.7 & 12.2 & 12.9 & 17.0 & 14.4 & 15.7 \\
\hline W4 & 120.7 & 69.0 & 94.8 & 18.9 & 16.7 & 17.8 & 35.2 & 25.2 & 30.2 \\
\hline W5 & 34.2 & 32.2 & 33.2 & 10.8 & 9.8 & 10.3 & 11.3 & 9.8 & 10.5 \\
\hline Mean & 62.1 & 43.8 & 52.9 & 14.2 & 12.6 & 13.4 & 19.6 & 15.8 & 17.7 \\
\hline \multirow[t]{2}{*}{ W } & \multicolumn{2}{|c|}{ S.Em \pm} & CD at $1 \%$ & \multicolumn{2}{|c|}{ S.Em \pm} & CD at $1 \%$ & \multicolumn{2}{|c|}{ S.Em \pm} & CD at $1 \%$ \\
\hline & \multicolumn{2}{|c|}{0.357} & 1.37 & \multicolumn{2}{|c|}{0.181} & 0.69 & \multicolumn{2}{|c|}{0.215} & 0.82 \\
\hline $\mathbf{D}$ & \multicolumn{2}{|c|}{0.319} & 1.22 & \multicolumn{2}{|c|}{0.162} & 0.62 & \multicolumn{2}{|c|}{0.192} & 0.73 \\
\hline WxD & \multicolumn{2}{|c|}{0.714} & 2.73 & \multicolumn{2}{|c|}{0.362} & & & & 1.64 \\
\hline $\begin{array}{l}\text { W1-Sew } \\
\text { D1 = 0 to } \\
\text { of triplic }\end{array}$ & epth & $\begin{array}{l}\text { Soft dri } \\
15 \text { to } 30\end{array}$ & $\begin{array}{l}y \text { waste } \\
h\end{array}$ & $\begin{array}{c}\text { W3- } p \\
\text { D3= }\end{array}$ & $\begin{array}{l}1 \text { waste } \\
\mathrm{cm} \mathrm{dep}\end{array}$ & $\begin{array}{l}\text { W4-dis } \\
\text { D4= } 45\end{array}$ & $\begin{array}{l}\text { twash } \\
\text { depth }\end{array}$ & ormal & $\begin{array}{l}\text { water } \\
\text { values mean }\end{array}$ \\
\hline
\end{tabular}


Table.7 Mn ( $\left.\mathrm{mg} \mathrm{kg}^{-1}\right)$ status in red, lateritic and black soils after passing 8 pore volumes of wastewaters

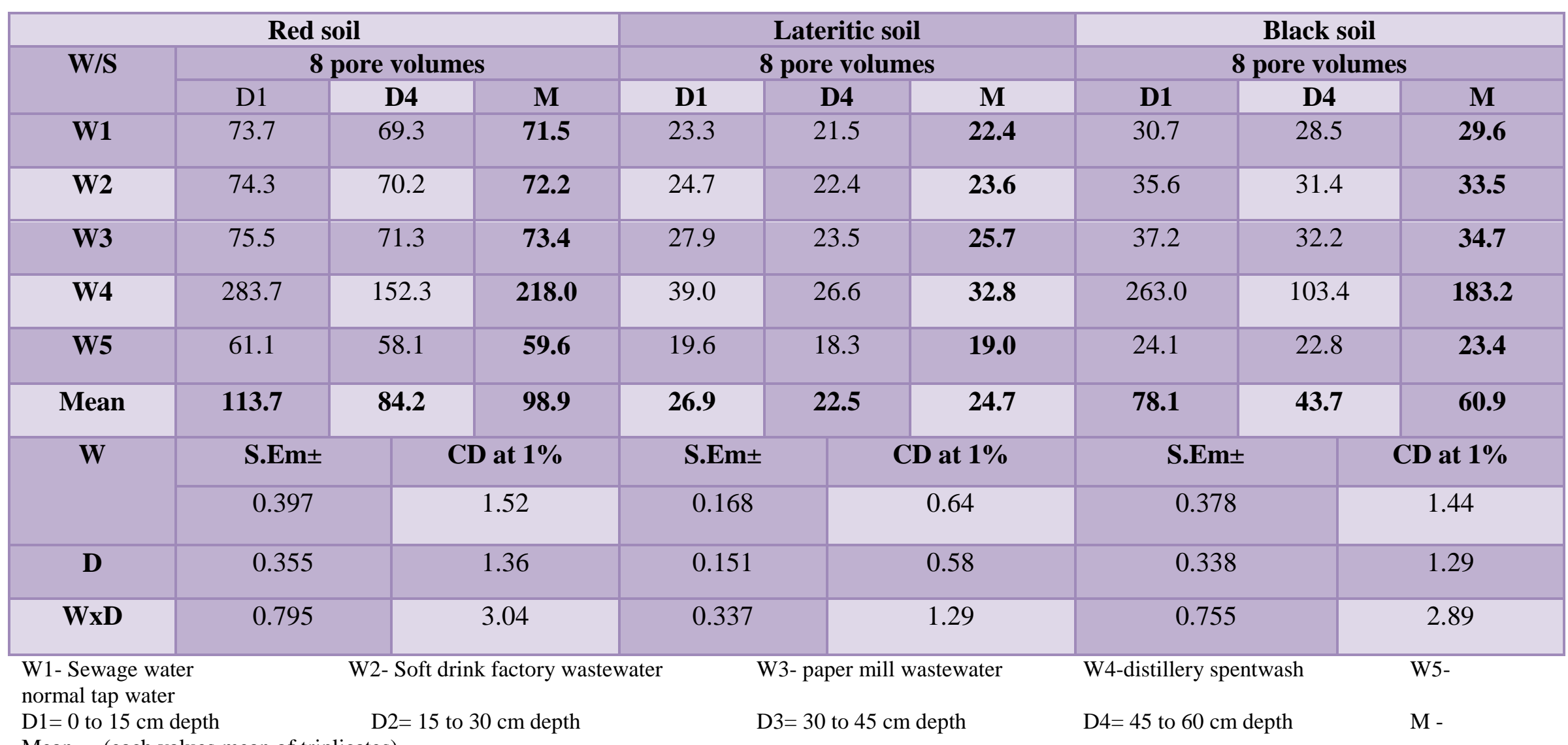

Mean (each values mean of triplicates) 
Effect of different wastewater on concentration of micronutrients

Available micronutrient status $(\mathrm{Fe}, \mathrm{Cu}, \mathrm{Mn}$, $\mathrm{Zn}$ and $\mathrm{B}$ ) of wastewater irrigated soils was higher compared to normal water irrigated soils due to addition of these micronutrients and also organic matter through different wastewaters (Table 3 to 7 ). Spentwash exerted maximum influence in enhancing the content of boron, zinc, iron, copper and manganese as all of these are high in it compared to other wastewaters. The boron content was least in lateritic soil is perhaps due to predominance of iron and aluminum oxides in these soils, which are known to adsorb boron. The higher boron content in red soils is related to its initial high content even with fresh water (Table 3). Sewage water ranked next to spentwash in enhancing boron content in all soils and copper content in red soil (Tables 3 and 4). While soft drink factory wastewater ranked next in respect of iron content, paper mill wastewater ranked next in respect of manganese content owing to their high content in respective wastewaters next to spentwash. Rattan et al., (2005) reported that sewage irrigation for 20 years resulted in significant buildup of DTPA extractable Zn, $\mathrm{Cu}$, and $\mathrm{Fe}$ in sewage water irrigated soils compared to tube well water irrigated soils (Table 4, 5 and 6). Vinod Kumar and Chopra (2011) concluded that application of various concentration of papermill effluent led to significant increase in the micronutrient concentrations in the soils. Singh and Swami (2014) also reported increased concentration of micronutrients in spentwash treated soils.

In conclusion, among the different treatments $\mathrm{W}_{4}$ significantly increased the boron concentration in soils under different pore volumes application. The general sequence followed was $\mathrm{W}_{4}>\mathrm{W}_{1}>\mathrm{W}_{3}>\mathrm{W}_{2}>\mathrm{W}_{5}$. The effect of wastewaters was higher in red soil followed by black soil and relatively less in lateritic soil as judged by mean boron content. The highest concentration of boron was recorded at surface layer and steadily decreased with the depth at all the pore volumes in all the soils.

The DTPA extractable copper, zinc, manganese and iron in the soils increased from 4 to 8 pore volumes application of various wastewaters and the content was highest with $\mathrm{W}_{4}$. DTPA extractable zinc in general was highest in red soil followed by black soil. lateritic non- soil had less DTPA extractable zinc. DTPA iron was appreciably higher with $\mathrm{W}_{4}$ especially in red and black soils. The DTPA extractable copper, zinc, iron and manganese were more at the surface $\left(D_{1}\right)$ than at $D_{4}$ in all the soils.

\section{References}

Gomez, KA. and Gomez, AA. 1984. Statistical Procedures for Agricultural Research. John Willey and Sons, New York (USA).

Hesse, R. 2002. A Textbook of soil chemical analysis. CBS publishers and distributors, New Delhi.

IWMI. 2006. Recycling realities: Managing health risk to make wastewater use an asset. Water policy briefing, issue 17 .

Jackson, ML. 1967. Soil Chemical Analysis. Prentice Hall of India Private Ltd, New Delhi.

Lindsay, WL. and Norwell, WA. 1978. Development of DTPA soil test for zinc, iron, manganese and copper. Soil Sci. Soc. American J., 42: 421-428.

Ratna, PR. Jagdish Prasad and Joshi, AP. 2008. Changes in soil properties due to irrigation with paper industry wastewater. J. Environ. Sci. Engg., 50(4): 277-282.

Sharma, V. Umesh, KG. and Deepak Arora. 2014. Impact of pulp and paper mill effluent on physico-chemical properties 
of soil. Arch. Appl. Sci. Res., 6 (2): 1217.

Singh, SV. and Swami, VK. 2014. Impact of distillery wastewater irrigation on chemical properties of agriculture soil. Int. J. Innovative Res. Sci. Engg. Tech., 3 (10): 17028-17032.

Sparks, DL. Page, AL. Helmake, PA. Loppert RH. Soltanpour, PN. Tabatabai, MA. Johnston, CT and Summer, ME. 1996. Methods of Soil Analysis, Part 3, pp. 610-624.

Tandon, HLS. 1998. Methods of Analysis of Soils, Plants, Water and Fertilizers.
Fert. Dev. and consultation Org., New Delhi, India, pp. 9-16.

Varkey, BK. Dasog, GS. Wani, SP. Sahrawat, KL. Hebbara, M. and Patil, CR. 2015. Impact of long-term application of domestic sewage water on soil properties around Hubli city in Karnataka, India. Agril. Res., 4(3): 272276.

Vinod Kumar and Chopra, AK. 2011. Alterations in physico-chemical characteristics of soil after irrigation with Paper mill effluent. J. Chem. Pharm. Res., 3(6): 7-22.

\section{How to cite this article:}

Hanamantarao Jogan and Dasog, G.S. 2019. Effect of Wastewaters on Concentration of Micronutrients in Dominant Soils of North Karnataka, India. Int.J.Curr.Microbiol.App.Sci. 8(04): 1059-1069. doi: https://doi.org/10.20546/ijcmas.2019.804.123 